\title{
Strategic management tools and their application in innovation processes
}

\author{
Iveta Kufelová ${ }^{1}$, Monika Raková, ${ }^{2 *}$ \\ ${ }^{1}$ University of Economics in Bratislava, Faculty of Business Management, Department of \\ Business Economy, Dolnozemská cesta 1/b, 85235 Bratislava, Slovak republic \\ ${ }^{2}$ University of Economics in Bratislava, Faculty of Business Management, Department of \\ Business Economy, Dolnozemská cesta 1/b, 85235 Bratislava, Slovak republic
}

\begin{abstract}
The development of new technologies and innovation processes lead companies to improve their processes, resulting in new products all the time. Throughout the product life cycle, a firm incurs various costs related to the activities carried out in the pre-production, production and post-production phases. The essence of strategic management tools is to optimize costs throughout the product life cycle, focusing on the different stages. Such tools include target costing, kaizen and life cycle costing
\end{abstract}

\section{Introduction}

The increasing importance of knowledge as an economic driver has major implications for innovation management. The systemic approach to innovation recognizes that innovation and knowledge generation take place as a result of a variety of activities, many of them outside the formal research process. In the current economic context, growth must mainly originate from increasing the productivity of knowledge work, and increasing this productivity is the most important contribution management can make. [15] The complex current managerial dynamics requires, not only immediate actions to ensure timely decisions in the present, but also a process of anticipation that allows to visualize possible scenarios in the future, through the application of methodologies and tools for the analysis of trends that facilitate the forecast of future situations or through the exercise of prospective in the construction of a desirable future. [14]

\section{Current state of the solved problem at home and abroad}

Cost management is the effort to provide the necessary information for the efficient use of resources in the products production that can compete in international markets in terms of time, cost, quality and functionality, thereby maximizing the profit of the enterprise and minimizing the costs. Cost leadership is to produce the same product at a lower cost than competitors without sacrificing quality. [12] There are several

\footnotetext{
* Corresponding author: monika.rakova@euba.sk
} 
ways how to optimize costs during innovation process. In this topic it has been defined three strategic management tools: life cycle costing, target costing and kaizen.

The product life cycles theory describes the general development of certain performance indicators of a product over its life time such as the development of turnover, profit rate as well as imports and exports. This development is typically divided and described in four phases-introduction, growth, maturity and degeneration. Phase one refers to the early exploratory stage which is characterized by a low market volume, uncertainty regarding the technological specification required by the market, simple product design and hardly any automatization in the production process. Phase two is specified as a growth phase with a large market expansion rate in which the dominant design emerges. Phase three marks the stage of maturity. Market growth slows down, innovations are less relevant and the number of companies decreases while market shares stabilize. [9] The product life cycle is significantly curtailed by rapid innovation and development in technology. It is a main driver of life cycle of products. In technology based industry, the lifecycle is shorter than before. [8] Companies focus on product-oriented in-novation during the growth stage of the industry life-cycle, and on process-oriented innovation during the maturity phase of industry evolution. [10]

Strategic cost management should provide cost information for both development and implementation of strategies, creating tactics to implement them, as well as development and implementation of control mechanisms for monitoring and reaching strategic objectives. Target costing was created during the 1960s in Japan by Toyota. Target costing is perceived as a strategic management system designed to manage costs of goods and services, seeking to identify new materials, at lower costs, for replacing components of the product, aiming to improve competitiveness. Target costing requires the participation of people from all sectors of the company, such as management, marketing, production engineering, cost accounting, and sales. [7] Target costing is not a costing system as such; rather it is an activity which is aimed at reducing the life-cycle costs of new products, while ensuring quality, reliability, and other customer requirements, by examining all ideas for cost reduction at the product planning, research and development process. [3] Target costing uses customer preference analysis to identify the implementable price and future sales volume. The product's cost structure is then optimized by matching drifting costs. The costing mechanism helps assign reasonable costs to products, matching customers' respective utility. This optimization assumes the independence of customer preferences resulting in an additive utility function. [2]

Kaizen as a lean management philosophy preaches continuous and progressive improvement of activities to create more value while reducing waste. It can be expanded to all areas of an organization. [11] Kaizen costing adopts a cost reduction system and assumes continuous improvement in production. The purpose of Kaizen costing is to reach cost reduction targets. Kaizen costing is a cost reduction method that helps to eliminate activities that do not add value to the product in the production process by continuous improvement. [12] Kaizen aims to promote continuous improvement, through multifunctional teams training and productive activities planning, with the objective of identifying gaps and developing new methods to solve possible issues. [13]

\section{Research Design}


The main objective of the paper is to clarify the strategic management tools that can be used during the different phases of the product lifecycle as well as during innovation, with respect to cost optimization.

Such strategic tools include target costing, kaizen and lifecycle costing with a focus on individual stages - pre-production, production and post-production.

In the preparation of the paper, sources on the subject from domestic and foreign authors were used. The obtained data were processed on the basis of analysis and synthesis, mathematical calculations and schemes.

The paper is rather theoretical in nature with the possibility of recommending how to use individual cost optimization tools in a company that wants to stay on the market in the long term and has a tendency to innovate.

\section{Result of the Paper and Discussion}

\subsection{Cost optimization during the product life cycle}

During the individual phases of the product life cycle, the company incurs various costs, that are related to the activities performed. First, they are the costs of activities in the pre-production stage, then the costs of production and finally the costs of processes in the post-production stage (dismantling of old technology, etc.). We refer to these costs in terms of drawing on the company's resources as the costs actually incurred.

The essence of strategic management tools is the optimization of costs during the entire product life cycle with a focus on pre-production stages.

Increasingly, many managers are inclined to say that increasing operational efficiency is not enough. That there is something else that will allow the company to become more successful.

In order to find resources and reserves to increase performance and profitability, it is necessary to monitor the entire value chain. The production and sale of products are associated with costs associated with all phases of the life cycle, not only during production. From an operational point of view, we get to strategic cost management, managerial accounting, which monitors the costs and revenues of the company from a long-term perspective. If a company looks at it from this point of view, it can give it a competitive advantage in the innovations. In many sectors, more emphasis needs to be placed on the importance of the pre-production stages of the product life cycle than on the production phase itself. These are mainly technologically and structurally demanding industries with an extensive phase of research and development (e.g. the automotive industry). On the one hand, the life cycle of products or services will be shortened, which means that it works at a time when products generate profit. On the other hand, the technological and organizational complexity of non-production stages is growing. Complications also include the fact that it is difficult to interfere with technological parameters during production, as well as the fact that it is not possible to influence cooperating entities at this stage.

It follows from the above facts, that a large part of the costs (sometimes up to between $80-90 \%$ ) is decided in the pre-production stages. If the company starts production, it has only small options for managing costs and purposefully influencing them.

The goal of strategic management and pricing decision-making is to focus on the costs in the pre-production stages and look for solutions to optimize them, as well as 
on the costs incurred during all stages of the product life cycle. One of the possible solutions to this problem is the use of the target costing method.

\subsection{Essence and implementation of the target costing method}

Target costing is currently one of the most widely used management accounting methods and an essential part of pricing decision-making processes. The method was developed at Toyota in 1965 and has been widely applied by companies in Japan since the 1970s. However, the principles of the method were already applied in the Bat'a shoe factories in the $1920 \mathrm{~s}$ in Czechoslovakia. The method is suitable for the production of more complex products, in research and development intensive production and in highly competitive industries, as well as for the innovation of already existing products. The production of complex products requires searching for new possibilities concerning the use of technology or construction solutions. Competition, in turn, forces companies to reduce costs.

Target costing method - is an activity aimed at verifying all possibilities of cost optimization in the phase of research, development and prototype preparation. The result of this activity should be a product design that meets all customer requirements and expectations, and the cost of its production and price will provide the company with the desired projected profit.

The basic steps of the target costing method include:

1. Determining the market price based on the market - customer requirements for the planned product.

2. Cost planning, which is aimed at influencing costs at the pre-production stage in an effort to achieve the lowest possible production costs.

3. Communication and cooperation at all levels (processes, departments, subcontractors, construction team, etc.)

The basis of this method is searching for the answer to the question: "What costs can the company spend on the product at a given market price?".

\section{Cost calculation using the target costing (TG) method}

The process of pricing using the target costing method is divided into the following stages:

1. Determination of target price and target cost.

2. Determination of the company's framework objectives -target profit.

3. Dividing the product into individual parts -functional units, levels.

4. Adjustment of planned costs to target costs and target price.

The TG method is extensively used in the automotive industry, as shown in the following example:

Suppose a model of a certain car is to be sold in the market for 116,900 . This amount represents the target selling price that customers are willing to pay for a given type of car. The firm aims to achieve a profitability of $10 \%$ of the selling price.

Target - selling price $16900 €$

Required profit surcharge $10 \%$ (of the selling price)

Target profit $1690 €$

Total - target cost $15210 €$ 
The calculated target cost of $€ 15,210$ should cover all the costs that the company has to incur to produce the car, which are:

- direct materials and semi-finished goods (semi-finished products),

- direct wages and other direct costs,

- overhead costs,

- a safety reserve (in case of unexpected circumstances),

- sales costs (matched with sales and distribution)

- marketing costs,

- research and development costs.

In terms of calculation of costs, the target costing method generally proceeds from the most general costs groups of a strategic character (research, development, marketing) to variable unit costs, which are deducted from the total cost.

The company further assumes that sales costs, research and development costs and strategic marketing costs will represent $38 \%$ of total costs. Overheads are assumed to be $30 \%$ of production costs. At the same time, it foresees a risk surcharge of $5 \%$ of the total cost of production. It expects wage costs and other direct costs to account for $25 \%$ of variable costs.

Calculation of variable costs per unit:

\section{Total cost}

- $\quad$ sales, research, development and marketing costs (38\%)

Production costs (to cover overheads and variable costs)

- overheads

- risk surcharge (safety margin)

\section{Variable costs per unit}

- wage costs and other direct costs

Direct materials and semi-finished goods
$15210,00 €$

$5779,80 €$

$9340,20 €$

$2802,06 €$ $467,01 €$

$6071,13 €$ $1516,78 €$ $4554,35 €$

Variable unit costs represent the maximum allowable level of costs within which a company must fit. They contain the costs of direct materials, raw materials, semifinished goods, semi-finished products, direct wages, other direct costs such as packaging costs, pallets, etc. When procuring the above-mentioned items, the company asks itself the question "which variable costs should we focus on, in order to meet the calculated amount?".

With fully automated machines or standardized performances, the possibilities to reduce direct labor costs are very limited. The right way can be found in reducing the costs of direct materials or raw materials and semi-finished goods (e.g. by diversifying suppliers).

The following figure shows the process of dividing the cost of a product into the individual components for which the company is making decisions with respect to their purchase price. The company's objective in this procedure is to find the level of direct material costs that corresponds to the desired cost level. For the construction of the entire product is responsible the construction team, which supervises for meeting the required costs, based on which it determines the costs for the individual components. 
Figure 1 Implementation of the target costing method [5]

\section{Target - selling price}

\section{Target costs}

Target profit

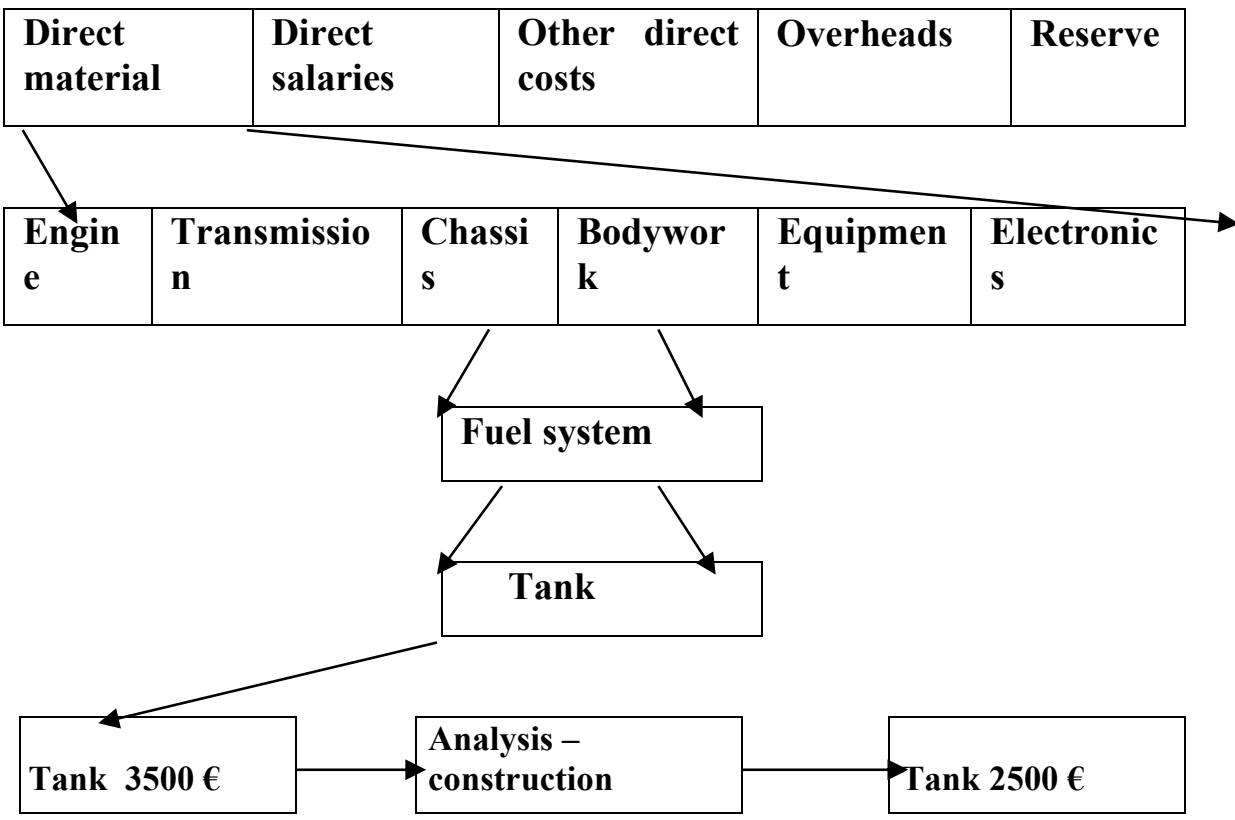

One of the main benefits of the target costing method is the strengthening of cooperation between individual departments of the company as well as professions, which have to cooperate efficiently and flexibly in the preparation as well as in the production of the product. The team involved in this must be composed of designers, technology and production staff, supply and marketing staff. The aim of all those involved is to design a product that will have all the features and functions required by customers, at a cost that will provide the company with the required profit.

Although the target costing method generally leads to cost optimisation, this reduction should not be associated with a reduction in quality or a reduction in the customer's perception of value. Another limitation of this method is that it works with estimated cost variables as well as estimated production volumes. Trying to get closer to the cost estimates may increase the time taken to prepare the product, which may lead to changes in input prices as well as in the customer preferences on which the target price was based and as a result, may have an impact on the projected - target profit.

\subsection{The kaizen costing method and the use of life cycle costing}

The kaizen method represents the introduction of smaller - continuous changes during the production phase of the product life cycle, in contrast to the TG method which 
focuses on the pre-production phase. Cost optimisation using kaizen is the most often achieved by increasing the efficiency of the production process through incremental changes in design and manufacturing processes, rather than undertaking major innovation projects.

The development of new technologies and innovation processes lead companies to improve their processes, resulting in new products all the time. Every product goes through a certain life process - the so-called life cycle - which they influence:

- the length of the life cycle,

- estimation of sales volume throughout the life cycle,

- estimation of the costs of each phase of the life cycle,

- analysis of the factors influencing costs and revenues during the life cycle.

Each stage is characterised by a different marketing situation, which also influences the choice of marketing mix strategy. During the life cycle, it influences its course:

Economic cycle - when economic changes in different areas need to be taken into account.

- Prosperity period - during this period the demand for a product increases. Prices are easier to increase, although costs also tend to rise. Costs rise more slowly than product prices. The difference between costs and prices affects the level of price, which influences firms' decisions on how to increase production capacity.

- Period of economic recession - in this period, buyers place emphasis on price. Firms reduce costs to a minimum level in order to keep prices low.

Distribution - is a factor that influences pricing decisions especially in small firms. Large firms are able to create their own market by spending large sums on advertising. Timely delivery of the product to the final customer requires important activities to be carried out which also affect the price. Smaller firms with limited resources have to use different distribution channels. They need to cooperate with them, but at the same time they need to take account of their reaction to their own pricing policy and be aware of the items that affect the price.

\section{Product type}

- Fashion product - the price of such a product is set at the discretion of the producers in the first period, as they know that there will always be customers willing to pay the price in order to show their serious interest in fashion. These firms therefore practise a policy of 'cream skimming', followed by a general reduction in prices after a more or less short period of time.

- Durable product - such product is not a source of impulse purchases. In deciding on the price, the firm relies on consultations at several levels and comparisons with competitors' products. In particular, product pricing must respect competitors' prices and the quality-price relationship of rival products.

- luxury product - some companies like to review the prices of luxury products. Luxury products can evoke a strong desire to have something special. If a firm launches such a new, lucrative product within its product range, it may be able to use its temporary, near-monopoly position to set the price. However, this pricing policy must also be expected to generate more competition, which will be attracted by higher profits.

- a basic demand product - there is no manipulative or manoeuvrable price range for these products. If buyers become accustomed to price reductions, they will reject any price increases and go to competitors.

\section{Psychological factors}


Every marketing (pricing) manager should monitor consumer buying behaviour, which is influenced by psychological factors. These are important to know in relation to pricing, in order to provide better, higher quality service to customers.

The following figure shows the relationship between target costing, kaizen and life cycle costing.

Figure 2 Life cycle costing [6]

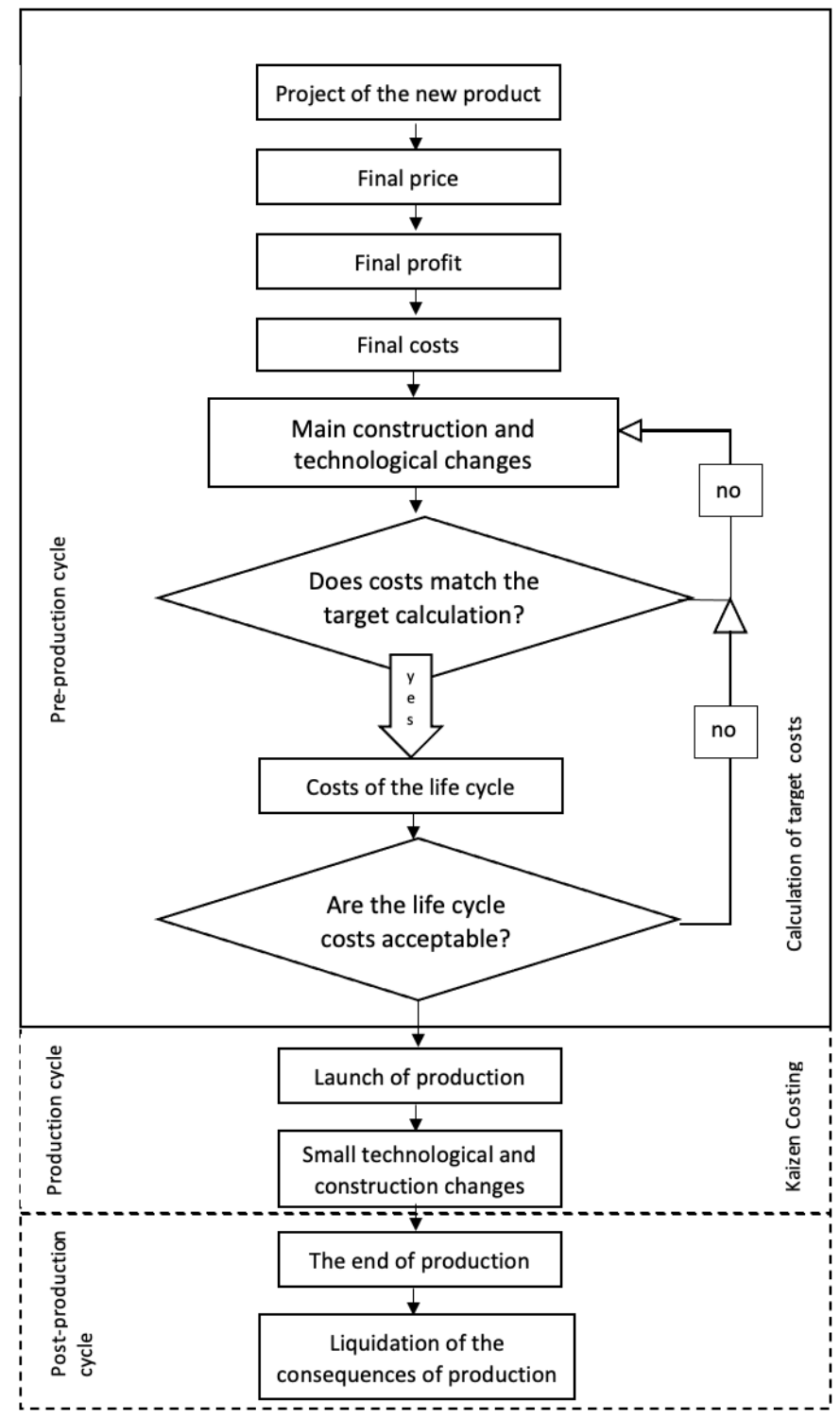

\section{Conclusion}

In business, almost all decisions are economic in nature. Thus, it is about comparing the benefits of business activity with the costs incurred, making a profit 
and maximising the market value of the business. In this respect, every company has to plan, calculate, record and manage costs mathematically. These activities enable managers to thoroughly understand and know the cost issues and, based on this, make decisions that are consistent with the company's goals and vision for the future.

It is about combining management, cost and financial accounting into a common cost management system, where the company can use cost optimization tools and thus compete in a fierce competitive battle. The emergence of these tools and related methods has been driven in particular by the development of information technology and the software tools available today, which are now a normal part of business and everyday life.

These strategic tools are aimed at optimising costs and achieving profitability through the volume of production (not by increasing output). As already mentioned, they are also suitable for innovation and can be considered as a competitive advantage of the company.

The article is an partial output of research project VEGA no. 1/0646/20 „Difúzia a dôsledky zelených inovácií na trhoch nedokonalej konkurencie, "in extent $50 \%$, and VEGA No. 1/0708/20: "Socioeconomic determinants of sustainable consumption and production in terms of impact on business performance and competitiveness" in extent $50 \%$.

\section{References}

1. E. Fendeková, I. Kufelová. Ceny a cenové rozhodovanie. Wolters Kluwer 2020, ISBN 978-80-7598-743-7. (2020)

2. C. Homburg, A. Hoppe, R. Schick, A. Braul. Accounting for preference dependency in target costing - a note. Review of Quantitative Finance and Accounting. doi:10.1007/s11156-021-00962-9. (2021)

3. K. Yutaka. Target costing support systems: lessons from leading Japanese companies. Manage Account Res, 4, 33-47. doi: https://doi.org/10.1006/mare. 1993.1002. (1993)

4. J. Kita, a kol. Marketing. Jura Edition 2010. Prvé vydanie. 411 s. ISBN 978-808078-327-3. (2001)

5. B. Popesko, Moderní metody rízení nákladu. Praha: Grada Publishing, $233 \mathrm{~s}$. ISBN 9788024729749. (2009)

6. L. Šoljaková. Manažerské účetnictví pro strategické rizeni, Management Press 146 s. ISBN: 80-7261-087-2. (2003)

7. A. A., Cunha Callado, A. L. C. Callado, E. T. Do Bomfim. Target Costing in Micro and Small Companies from The IT Sector. Revista Evidenciação Contábil \& Finanças, 8, 125-141. doi:10.22478/ufpb.2318-1001.2020v8n3.50245. (2020)

8. Y. Sun, H. H. Cai, R. Su, Q. Shen. Advantage of low quality in short life cycle products. Asia Pacific Journal of Marketing and Logistics, 32, 1038-1054. doi:10.1108/apjml-03-2019-0148. (2019)

9. M. O'Sullivan. Industrial life cycle: relevance of national markets in the development of new industries for energy technologies - the case of wind energy. Journal of Evolutionary Economics, 30, 1063-1107. doi:10.1007/s00191-020-00677-5. (2020) 
10. M. Cucculelli, V. Peruzzi. Innovation over the industry life-cycle. Does ownership matter? Research Policy, 49, 103878. doi:10.1016/j.respol.2019. 103878. (2020)

11. E. E. Jeunon, F. de Oliveira Júnior, L. da Cunha Duarte, E. H. R. Guimarães, E. Lean manufacturing implantation impacts: a study on a large logistics operator. Revista Gestão \& Tecnologia, 20, 305-319. (2020)

12. D. Kelesbayev, H. Kozhabayev, G. Mombekova, R. Yermankulova, B. Dandayeva. An application for reduction of the non-value activities by Kaizen costing method in the Kentau Transformer Plant. Entrepreneurship and Sustainability Issues, 8, 182. (2020)

13. L. S. Valamede, A.C.S. Akkari. Lean 4.0: A New Holistic Approach for the Integration of Lean Manufacturing Tools and Digital Technologies. International Journal of Mathematical, Engineering and Management Sciences, 5, 851-868. doi:10.33889/ijmems.2020.5.5.066. (2020)

14. EE. Minguet-Carvajal. Management prospective. Background, currents and prospective worldviews at the philosophical and praxeological. Vision GERENCIAL, 19, 61-74. (2020)

15. A. Hidalgo, J. Albors. Innovation management techniques and tools: a review from theory and practice. $R \& D$ Management, 38, 113-127. doi:10.1111/j.14679310.2008.00503.x. (2008) 